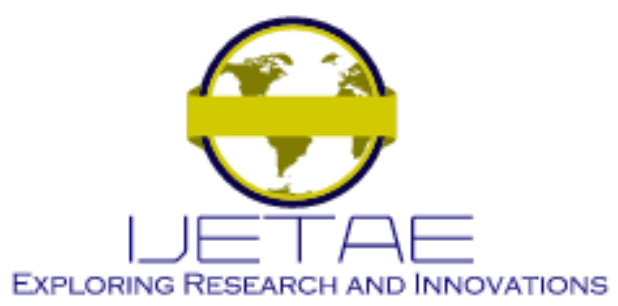

International Journal of Emerging Technology and Advanced Engineering

Website: www.ijetae.com (E-ISSN 2250-2459, Scopus Indexed, ISO 9001:2008 Certified Journal, Volume 11, Issue 09, September 2021)

\title{
Design of a Ventilation Control System in Underground Mines and Tunnels
}

\author{
Marcos Hernández-VaraCadillo ${ }^{1}$, Brian Meneses-Claudio ${ }^{2}$, Alexi Delgado ${ }^{3}$ \\ ${ }^{1,2}$ Universidad de Ciencias y Humanidades \& Av. Universitaria 5175, Los Olivos 15304 \\ ${ }^{3}$ Pontificia Universidad Católica del Perú \& Av. Universitaria 1801, San Miguel 15088
}

\begin{abstract}
Today no one is free of accidents, especially in high-risk work environments such as in-mine and/or tunnel work. It is quite common that in this type of high-risk activities and where evacuation accesses are distant from the area of operations, the response time plays an important role in the event of a dangerous event, which can materialize in an accident if necessary. you do not act quickly. Having a realtime ventilation monitoring and control system helps us as a tool to prevent a possible risk event. This control system, by constantly monitoring the ventilation inside the tunnel or inside the mine, can send us an alert to a web server that can be monitored through a computer and/or a smartphone that is on the surface when there is a lack of air, when the temperature rises considerably and the humidity begins to rise or the air flow is minimal then the system will activate an alert to the different monitoring or control devices. Additionally, this prototype contributes to saving energy because it will automate the switching on of the fans only in the presence of people in the work area. This prototype thus achieves real-time supervision and allows us to make the best decision when faced with an event that endangers human life in the workplace.
\end{abstract}

Keywords-Temperature; esp-32; Arduino; air sensor, mine, ventilation, work safe

\section{INTRODUCTION}

Today mining in Peru and the world is a high-risk activity, which can cause accidents in their daily operations. Work accidents are generally caused by unsafe acts, inadequate conditions caused by the same people and in some cases by the environment. Therefore, reducing and avoiding any emergency is the responsibility of all actors in the mine labor process[1].

We can mention the largest case of mining rescue in the world, which happened in August 2010, in the San José mining (located in Chile), where thirty-three male miners were trapped approximately 720 meters below the surface. The insufficient ventilation produced temperatures of around $50^{\circ} \mathrm{C}$, which, according to the miners themselves, it was difficult for them to bear [2].
The lack of ventilation inside the mine is a frequent problem in those work areas, especially when there are accidents where they are trapped and there is little or no ventilation. Work in underground mines is generally high risk, because they are the ones that generate the most fatalities in accidents, as shown by the annual statistics presented in Peru, as reported by the Organismo Supervisor de la Inversión de la Energía y Minería (OSINERGMIN). In Peru in 2019, mining accidents reached 19 fatalities, $37 \%$ in surface mining and $63 \%$ in underground mining, in 2018 mining accidents reached 23 fatalities, 35\% of which surface mine and $65 \%$ underground mine. [3] This certainly reflects that the underground mine is high risk.

Underground mining presents various accidents with consequences of fatal lives, but we can mention that the lack of ventilation inside the mine, places it with an annual average of $16 \%$ of incidents with respect to fatal accidents. Lack of ventilation within underground levels puts human life at risk, [4] poor ventilation in the work area is a high and fatal risk.

According to DS 055-2010, Safety and Health Regulations for Mining Operations Management, in Chapter IV, Article 236 indicates: The mining owner will provide clean air to work tasks according to the needs of the worker, the equipment and to evacuate gases, fumes and suspended dust that could affect the health of the worker. Every ventilation system in the Mining activity, as regards air quality, must be kept within the occupational exposure limits for chemical agents according to ANNEX No. 4 and the provisions of Supreme Decree No. 0152005-SA or the regulation that modifies or replaces it [5].

Inside, the air is deficient and often scarce, so it is necessary to use fans and extractors to remove the polluted air, which is often called stale air, therefore it is necessary to optimize ventilation [6]

The main objective of this research work is to be able to have an alert system, which indicates the status of the fans inside the mine. 


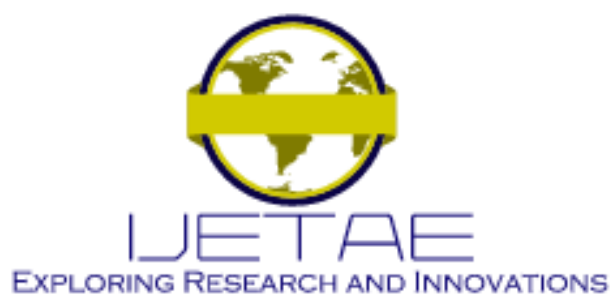

International Journal of Emerging Technology and Advanced Engineering

Website: www.ijetae.com (E-ISSN 2250-2459, Scopus Indexed, ISO 9001:2008 Certified Journal, Volume 11, Issue 09, September 2021)

Through a prototype developed with a Devkit ESP32 card (NodeMCU-32 development board) that will send the alert to a supervisory point at the surface control center. With this, it will be possible to determine if a fan is not working and providing the fresh air that is required, being able to avoid risks and accidents in the work inside the mine due to lack of fresh air.

The ESP32 is a microcontroller manufactured by the Espressif Company (Company dedicated to the manufacture of microcontrollers and development boards). The ESP32 DEVKIT-C development card allows us to have GPIO digital inputs and outputs (general purpose inputs and outputs), it has integrated $\mathrm{Wi}-\mathrm{Fi}$, which allows us to transmit data wirelessly, these boards are widely used on the internet of things (IoT). It has a dual-core processor up to $240 \mathrm{MHz}$ (Mega Hertz) and can be programmed in an Arduino environment. (free software to program Atmega microcontroller). [7]

The following research work is structured as follows: In section II, the prototype that sends an alert when the fan inside the mine stops working will be presented. In section III, the results of the internal mine fan failure alert prototype will be shown when it is inoperative or when it stops working and, in this way, it will alert the personnel on the surface. In section IV, we present the discussions of the research work and finally in section $\mathrm{V}$, the conclusions, as well as the future work that is intended to be reached with the research work.

\section{LITERATURE REVIEW}

In [8], the Ventilation On Demand (VOD) system, also called Smart ventilation, constitutes a factor of prevention against occupational health and of automation to the system. Thus, having better control and management, under the best way to distribute the ventilation points and use them properly where it is required to be on or with less power, avoiding accidents and saving electricity, they use the HMI (Human Machine Interface) system. Achieving better control of fresh air in places where it is required to ventilate the areas to be used.

In [9], they indicate that having a control of the fans, helps in saving energy and additionally provides fresh air in the working atmosphere in the mine.
The system was based on a feedback of air flow data, using mathematical algorithms that model the system to be implemented. The result that is obtained is a better performance of the fans already installed.

In [10], he describes us that the ventilation system inside the mine can be more efficient with an automation system, taking advantage of energy efficiency and obtaining a controlled recirculation, by formulating an algorithm for the location of the air inlet and outlet doors, using MATLAB, it is possible to have the necessary groups for the optimization of the system. They managed to get a better air distribution, placing the fans in the right places.

In [11], he describes us that environmental factors in a tunnel-type greenhouse influence plant growth, for which he proposes to have a control system for temperature, humidity, sunlight, to stop using a manual record. The system is based on obtaining variables of temperature, humidity, lighting, by means of an Arduino uno and taken to a graphical interface where it shows us the different levels of the variables. It is a system of great help in the work of being able to monitor the greenhouse, saving manhours and being able to handle data from the variables, as well as being able to modify the predetermined values for some type of different crop.

In [12] he indicates that being able to have remote control and monitoring is necessary in different plants and this is the case of a pressure regulator, they developed a remote monitoring and control system to regulate pressure using MATLAB programming platforms. and HTML, and the Arduino and Ethernet Shield boards, which is based on the Internet of Things (IoT), using the web platform for monitoring. The fundamental development was to be able not only to monitor a pressure regulator, but to be able to apply it to different uses and even to engineering laboratories.

\section{MethodOLOGY}

In this section, the steps to be followed are developed to detect the lack of ventilation inside the tunnel or sinkhole inside the mine and to be able to send an alert to a control center on the surface. Figure 1 shows the steps to be followed by the system for its correct operation. 


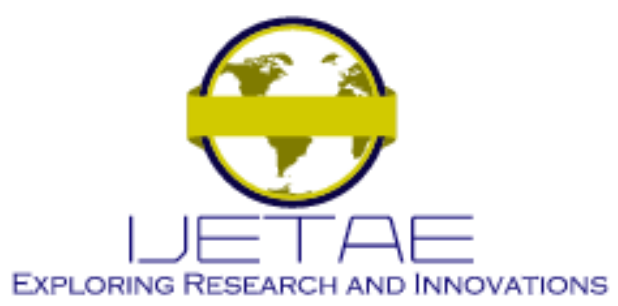

International Journal of Emerging Technology and Advanced Engineering

Website: www.ijetae.com (E-ISSN 2250-2459, Scopus Indexed, ISO 9001:2008 Certified Journal, Volume 11, Issue 09, September 2021)

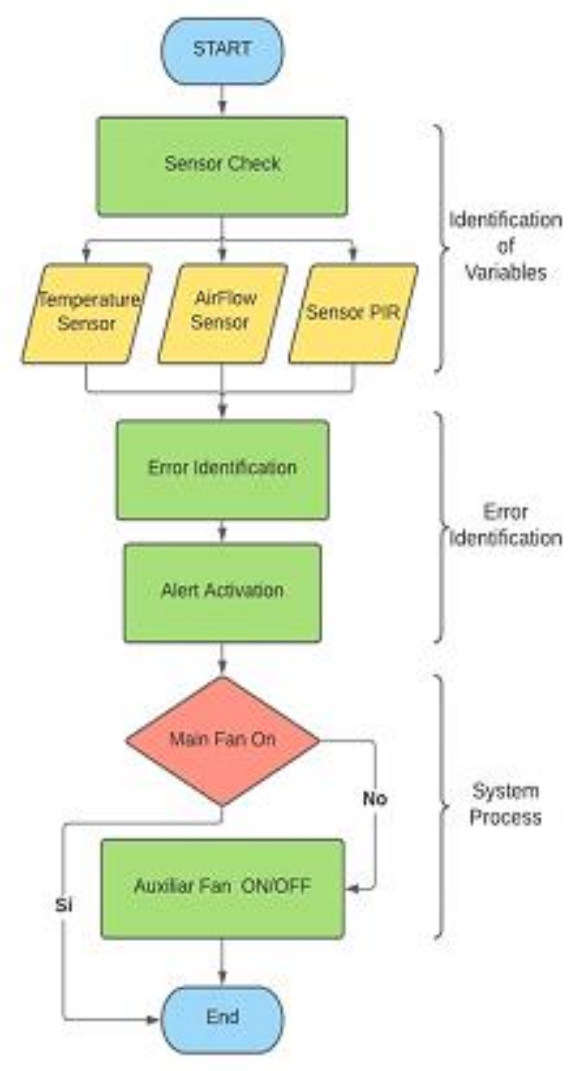

Fig. 1. Flow diagram of the control and alert system for indoor mine fan

\section{A. Identification of variables}

To obtain the different variables in the prototype of the ventilation control system, we will use in this prototype: 3 sensors, such as temperature and humidity, Air flow, Presence sensor.

In order to obtain the temperature and relative humidity in the area to be monitored, the DTH22 sensor is used, which is a temperature sensor with a range of $-40^{\circ} \mathrm{C}$ to $80^{\circ} \mathrm{C}$ with a precision of $+/-0.5^{\circ} \mathrm{C}$ and a humidity range of $100 \% \mathrm{RH}$ and precision of $2 \% \mathrm{RH}$, with time between readings of 2 seconds. [13]

In Figure 2, we can see the DHT22 temperature and humidity sensor, model AM230, which consists of three pins: vec, gnd and data.

In our prototype, the digital temperature sensor will be energized with 3.3 volts and the data output will be connected to a NodeMcu card (development board for prototypes of projects on the Internet of Things).

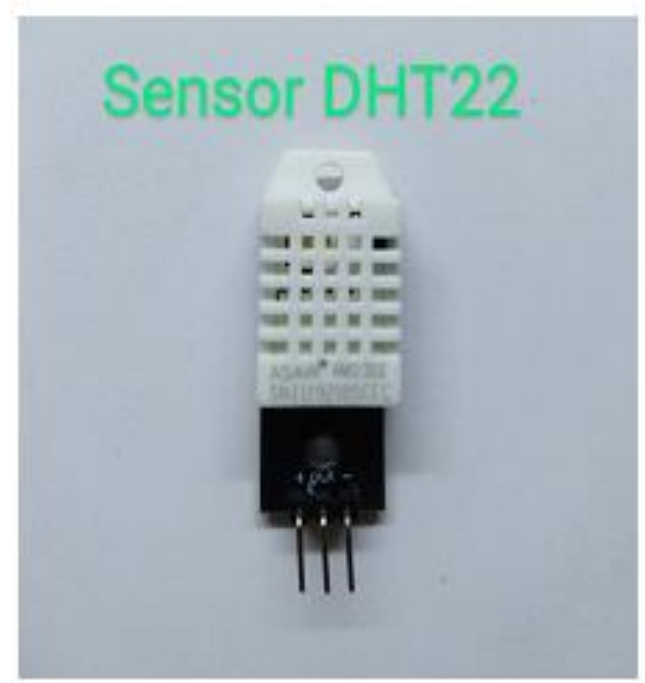

Fig. 2. Sensor AM2302

The digital temperature and relative humidity sensor is inexpensive, which is at an average market value of 20 PEN.

To determine the air flow, a fan-type anemometer [14], was used, which was built on the basis of a fan and the relation of the movement of the blades of this that served to take a sample of the presence of air in interior mine. This sensor will allow us to always have the adequate level of air flow registered in the area where the fan is operating, it could also give us an advance warning of some wear or anomaly in the ventilation system when losing force in the air flow such as it was possible to check with our anemometer in Figure 3. For this, the AD0912HS-A76GL model fan, from the ADDE Brand [15] used many times in desktop computers, is used. This type of fan has three terminals, two for its power supply and the other as a hall effect sensor [16], which will be connected to the ESP32 card to record the entry of this variable, air flow in the area.

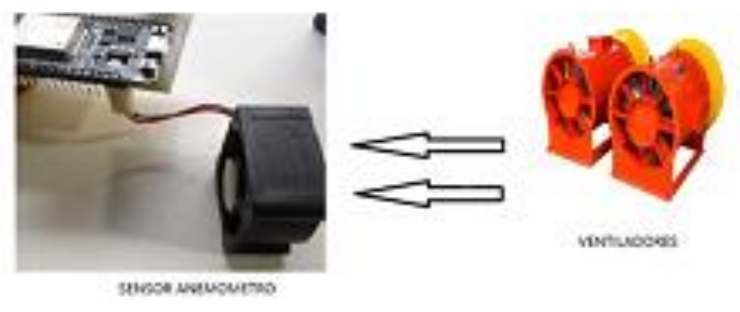

Fig. 3. Prototype anemometer sensor 


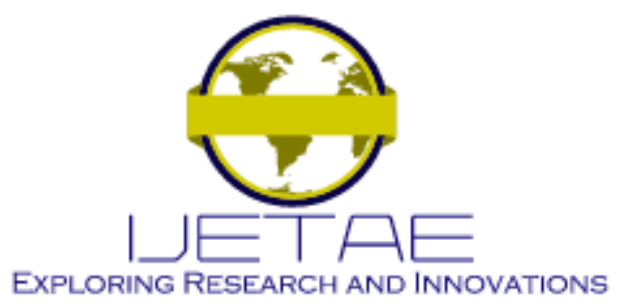

International Journal of Emerging Technology and Advanced Engineering

Website: www.ijetae.com (E-ISSN 2250-2459, Scopus Indexed, ISO 9001:2008 Certified Journal, Volume 11, Issue 09, September 2021)

Through the PIR sensor (infrared motion sensor), the model used in this prototype is HC-SR50, which is a passive infrared sensor, which has a range of 7 meters and an opening angle between $90^{\circ}$ and $110^{\circ}$, as we can see in Figure 4.

The PIR sensor has an operating voltage of 5 to 20 VDC, and an average consumption of $60 \mathrm{~mA}$, thanks to its low current consumption it is of great help in the control system, it is adjustable in the firing pulses by means of the adjustable resistors on its electronic card, the model has dimensions of $32.7 \mathrm{~mm} \times 29 \mathrm{~mm}$, which makes it an easy-toinstall sensor. There are various brands on the market, but the most commercial is ToToT, of Chinese origin. [17]

This PIR sensor will give us the sample if there is presence in place or work area so that the fan turns on and the fan turns off and does not generate unnecessary energy consumption, this will not only help to monitor the presence of personnel in the area. [18]

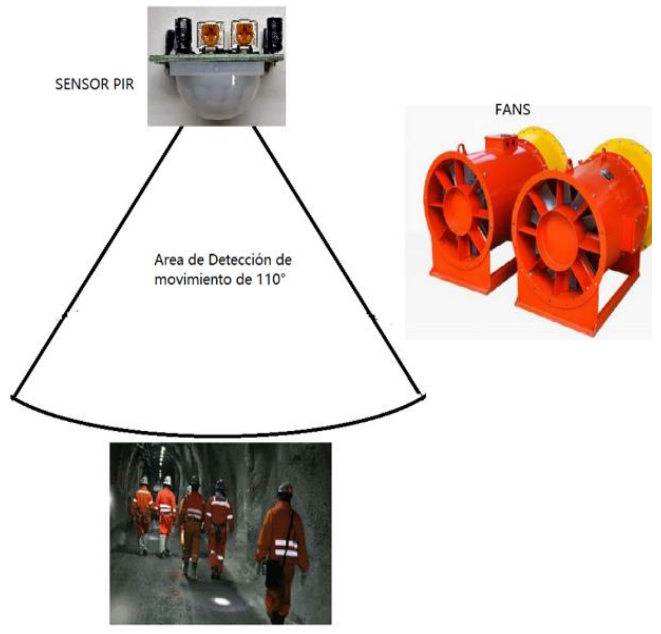

Fig. 4. PIR sensor range

Through this sample, the decision can be made as to whether it is necessary to have to work with an auxiliary fan to help send fresh air to the place.

The thermo-environmental conditions inside the mine depend on the temperature, speed, and humidity of the air.

Relative humidity is the degree of saturation of water vapor in the air at the temperature of the air.

The allowed temperature values inside the mine according to the current regulations are shown in the table in Table I, where you can see the levels allowed inside the mine
Table 1

Temperature And Humidity Values In The Work Area

\begin{tabular}{|l|l|l|}
\hline & Temperature & $\begin{array}{l}\text { Relative } \\
\text { Humidity }\end{array}$ \\
\hline $\begin{array}{l}\text { Optimal (work in } \\
\text { comfort) }\end{array}$ & 18 a $21^{\circ} \mathrm{C}$ & $55 \mathrm{y} 65 \%$ \\
\hline Allowed & $21-27^{\circ} \mathrm{C}$ & $>65 \%$ \\
\hline Alert Zone & $>27^{\circ} \mathrm{C}$ & $<55 \%$ \\
\hline
\end{tabular}

Not only indoors does the temperature affect work performance, but through the following table of temperature versus efficiency, it can be observed that performance is reduced as the work area increases in temperature.

Our temperature control system and warning of the absence of ventilation in the work area, can also contribute to work performance.

In Table II, we can see that the temperature influences the efficiency in the performance of its work, the higher the temperature, the lower the efficiency.

Table 2

Allowed Temperature and Humidity values in the Work Area

\begin{tabular}{|c|c|}
\hline Temperature & $\begin{array}{c}\text { Work } \\
\text { efficiency }\end{array}$ \\
\hline $20{ }^{\circ} \mathrm{C}$ & $97 \%$ \\
\hline $25^{\circ} \mathrm{C}$ & $90 \%$ \\
\hline $30^{\circ} \mathrm{C}$ & $80 \%$ \\
\hline $32{ }^{\circ} \mathrm{C}$ & $60 \%$ \\
\hline $35^{\circ} \mathrm{C}$ & $42 \%$ \\
\hline $40{ }^{\circ} \mathrm{C}$ & $25 \%$ \\
\hline
\end{tabular}

The temperature variables obtained will be in the following range as shown in table 3 for our control system.

Table 3

Range Allowed In Our Prototype

\begin{tabular}{|c|c|c|}
\hline Temperature & Allowed & Not allowed \\
\hline & $18<\mathrm{T}^{\circ}<21$ & $\mathrm{~T}>27^{\circ}$ \\
\hline
\end{tabular}




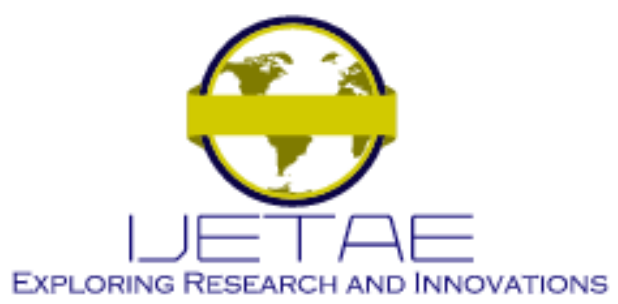

International Journal of Emerging Technology and Advanced Engineering

Website: www.ijetae.com (E-ISSN 2250-2459, Scopus Indexed, ISO 9001:2008 Certified Journal, Volume 11, Issue 09, September 2021)

The presence sensor will record 3 to 7 meters, to have control of being able to activate or deactivate the fan and this will contribute to the useful life of the fans and to energy savings, by having a fan on in places where it is not required

\section{B. Processing of obtained Variables}

The variables obtained through the temperature, air flow and presence sensors will be processed by the DEVkit ESP32 development card that has general purpose inputs and outputs (GPIO).

In figure 5 we can see the Development board used in our control system made.

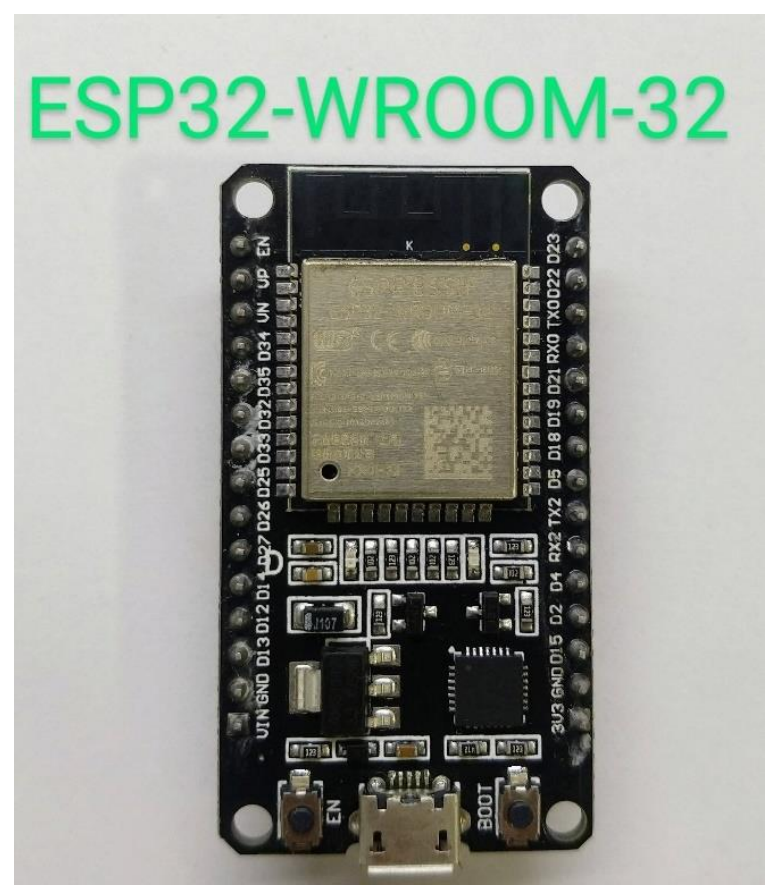

Fig. 5. DEVkit ESP32

The ESP-32 platform allows the development of applications in different programming languages, but for our prototype the Arduino in $\mathrm{C}++$ will be used, with the respective libraries of the sensors to be used.

In table IV, we can see some characteristics of the ESP32-WROOM-32 card, DEVkit-ESP32 [19] with which we will process all the variables and then send them through a wireless connection to the web data server.
Table 4

ESP-32 Characteristics

\begin{tabular}{|c|c|}
\hline Characteristics & ESP32-WROOM-32 \\
\hline $\begin{array}{c}\text { Power supply } \\
\text { voltage (usb) }\end{array}$ & 5 VDC \\
\hline $\begin{array}{c}\text { Input and } \\
\text { output voltage }\end{array}$ & 3.3 VDC \\
\hline Board & ESP32 DEVKIT V1 (Espressif) \\
\hline CPU & Dual core Tensilica Xtensa LX6 \\
(32 bit)
\end{tabular}

The variables obtained must meet certain parameters to be able to know if they are outside the allowed ranges and to be able to establish if it is a normal or abnormal state.

This card also has an integrated Wi-Fi connection, which facilitates communication through the existing network. It is also possible to send the data through $\mathrm{RS} 232$ communication protocol. [7]

The sampling time of the variables obtained will be in intervals of 10 seconds, for the temperature sampling.

The program will determine if the temperature is in the allowed range, otherwise it will send an alert indicating that it is outside the allowed range and will activate the auxiliary fan as a control option and be able to stabilize the temperature, otherwise it will have to send an alert to evacuate area.

The PIR sensor will sample the presence of someone in the workplace. The sensor is connected to the ESP32 card via GPIO inputs, as shown in figure 6. 


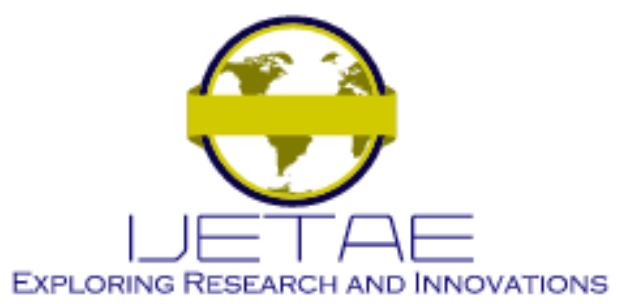

International Journal of Emerging Technology and Advanced Engineering

Website: www.ijetae.com (E-ISSN 2250-2459, Scopus Indexed, ISO 9001:2008 Certified Journal, Volume 11, Issue 09, September 2021)

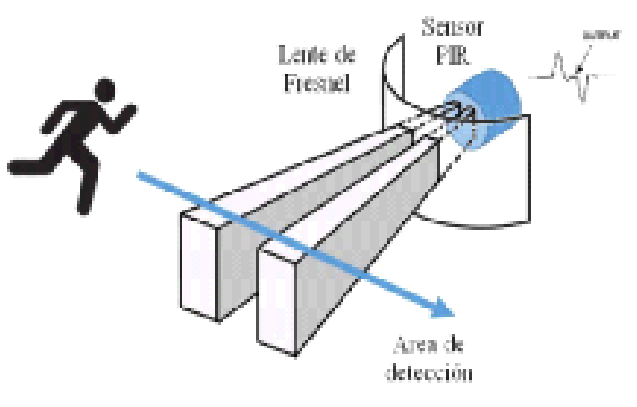

Fig. 6. PIR sensor work

\section{Monitoring and Alert System}

The monitoring system will be based on a visual and audible alert that allows us to have an alert that the ventilation system of the work area is inoperative and puts people at risk in that place.

For the real-time control of the sensors such as temperature and presence in the area, the thingspeak web platform will be used, [20] which is an application for the collection and storage of IoT (Internet of Things) data, open source and through the HTTP protocol (Hyper Text Transfer Protocol) [21] web server https://thingspeak.com/channels/1411561 which shows us in real time the status of temperature and humidity, also there is an alert high temperature in the work area as shown in Figure 7.

We can also visualize in the figure, the different windows that initially show us a real-time temperature of $26.5^{\circ} \mathrm{C}$ and to its right a visual alert in red of abnormal temperature, which shows us a high temperature alert record in the place, in the same way an analog screen of humidity percentage is seen, being in normal parameters and the next window shows us, presence in the work area with a green indicator that informs that the fans are in the activated zone.
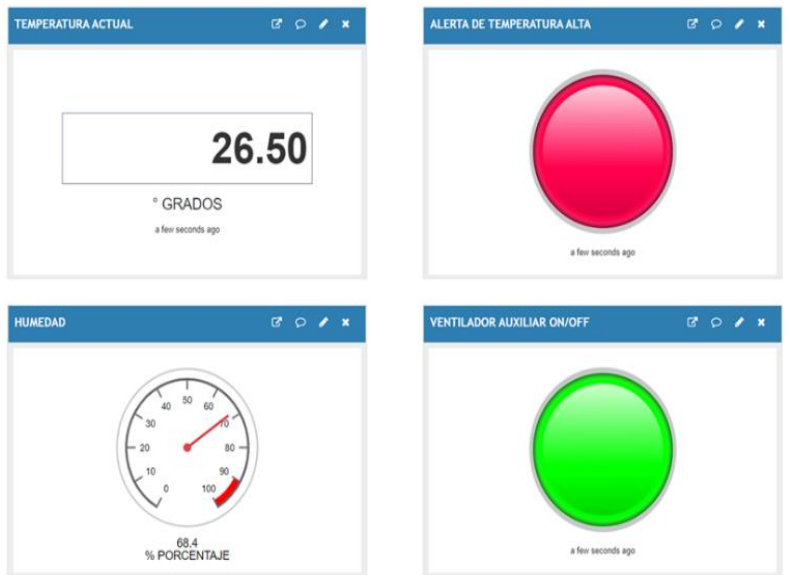

Fig. 7. Web platform used- real time data

We can have a history in time about the temperature of the area as shown in Figure 8.

Thanks to the use of the ThingSpeak web platform, we can keep a record of the values obtained, for their respective evaluation, being able to be exported in excel format, and being able to have a database with the monitored parameters of the respective área.

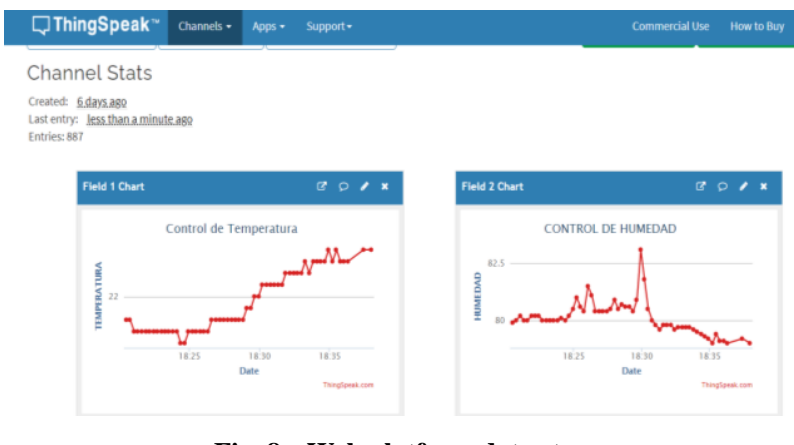

Fig. 8. Web platform data storage

Finally, our prototype is based on 3 variables which are the temperature sensors, anemometer, and the use of the PIR. In the future, this prototype will have more sensors to have better control in the system. In Figure 9, we can see the prototype. 


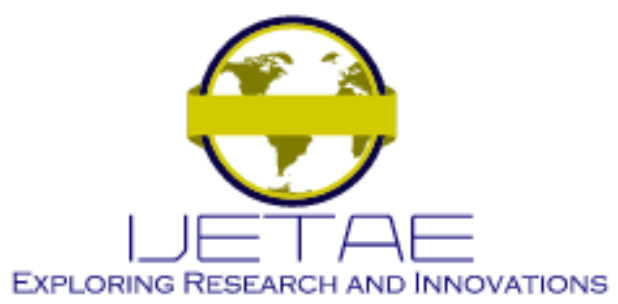

International Journal of Emerging Technology and Advanced Engineering

Website: www.ijetae.com (E-ISSN 2250-2459, Scopus Indexed, ISO 9001:2008 Certified Journal, Volume 11, Issue 09, September 2021)

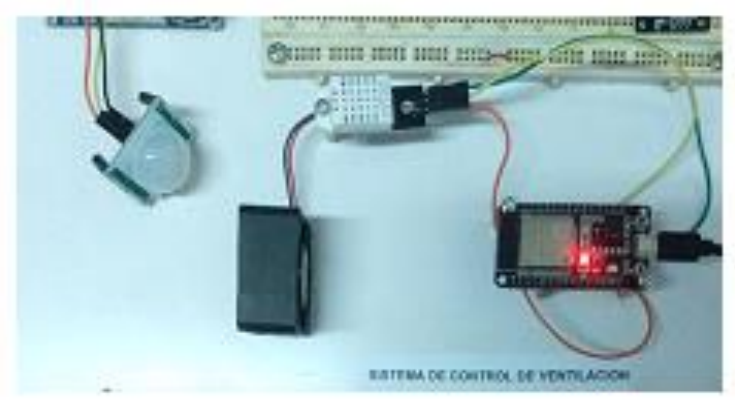

Fig. 9. Prototype

\section{RESULTS}

After obtaining the samples obtained through the three sensors used such as temperature, air flow and presence sensor, we can have a prototype of a ventilation control system in closed environments such as underground mines.

When the environment temperature exceeds the values established as normal, the system will send a high temperature alert and it may be stabilized by activating an auxiliary fan, achieving as a result controlling the ambient temperature and being able to have fresh air.

In areas where there is an absence of personnel, the system will send a notice of non-presence in the area and the fan must be deactivated, achieving energy savings, and maintaining the useful life of the fan.

With the air flow sensor, it will be possible to obtain the necessary levels to be able to monitor the proper functioning of the fan, which will record if there is exhaustion on the part of the fan and be able to schedule its maintenance, as a result an early diagnosis is obtained and be able to take the corrective action before the fan stops operating, also being able to prevent lost working hours.

Finally, using the web control system, it will be possible to monitor in real time and be able to keep a record of the values obtained from the different sensors that will help decision-making in the event of an eventuality.

In figure 10, it shows us the general scheme of the Control System.

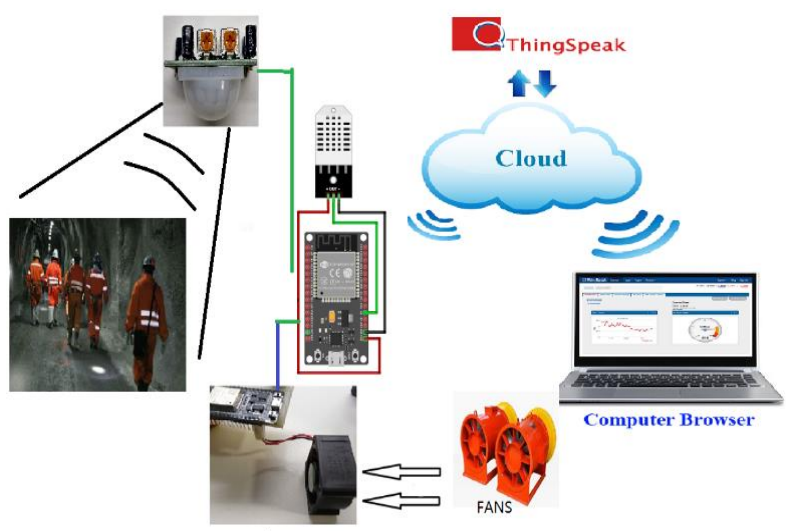

Fig. 10. Prototype control systems and web platform

In Figure 11, we can see normal operating parameters where the temperature is in the allowed range that we have established in table III as normal operating parameters, a temperature of $19^{\circ} \mathrm{C}$ is seen and the high temperature alert is off.

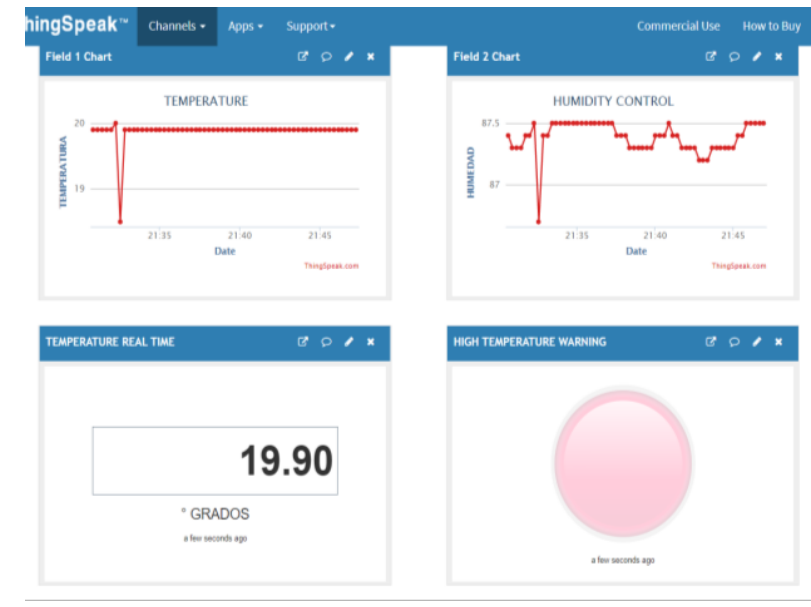

Fig. 11. Normal working area temperature

In Figure 12, we can visualize abnormal operating parameters where the temperature is in an unauthorized range that we have established in Table III as normal operating parameters, the temperature is above $25^{\circ} \mathrm{C}$ and the high temperature alert is found on and that is when the system generates the alert to all the devices connected to the thingspeak web platform. 


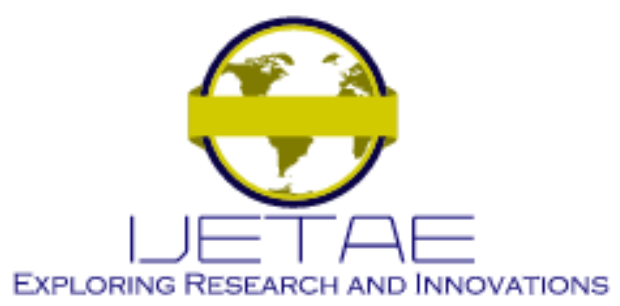

International Journal of Emerging Technology and Advanced Engineering

Website: www.ijetae.com (E-ISSN 2250-2459, Scopus Indexed, ISO 9001:2008 Certified Journal, Volume 11, Issue 09, September 2021)

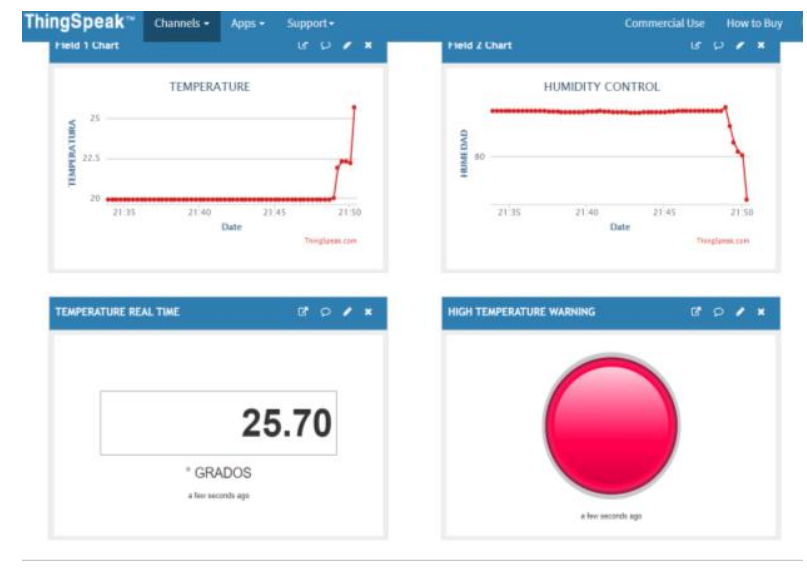

Fig. 12. Alert system temperature $>25^{\circ} \mathrm{C}$

\section{DISCUSSION}

According to the research work [22], we can establish a similarity since we work with sensors such as temperature, air flow that wirelessly take samples of the data and send them remotely to process the received data.

Our research work will help to maintain optimal control of the air flow, because it will establish through the different sensors an ignition of fans when there is presence of personnel in the work area in difference to [8], it can indicate that our work will help to maintain an optimum control of the fan status, thanks to the constant monitoring of the air flow that it generates a variation within the usual parameters, would indicate a depletion in the fan, which alerts us very early on a possible failure

According to the research work [10], we can indicate that it is very similar since our research work is also aimed at being able to keep the fan off when there is no presence of people in the area, thus prolonging the useful life of the fan and a saving in energy consumption, additionally an economic saving for the company.

Our research work in relation to [9], differs because it maintains an average temperature control of $25^{\circ} \mathrm{C}$ and alerting to temperatures higher than $27^{\circ} \mathrm{C}$, this range is variable and adjustable according to the requirement of the area of operations.

According to the research work [11], the data obtained is shown in a graphical interface, using management software, compared to our work it differs, because ours can be viewed from the web environment, or any device with internet access, being able to monitor in real time from anywhere, without being close to the monitoring area. In addition, it can be seen simultaneously by several devices.

\section{CONCLUSIONS}

We can conclude that this research work contributes to the prevention of incidents and/or accidents inside the mine due to errors that are caused by ventilation.

It is necessary to have a real-time temperature monitoring, since all this visualized by the web platform, allows us not only to have a control but also to keep a record that serves as a report based on work performance in relation to temperature and make decisions in dangerous situations for personnel in the risk area.

By preventing problems with ventilation, it also saves time from lost working hours. Less working hours, less production. Greater control of ventilation and actions taken appropriately with the speed that is required in situations that require it, the higher the production and the greater the well-being and safety for the personnel working in the corresponding areas.

In addition, it contributes to saving energy, which is important to protect the environment.

Also, an energy saving in terms of the decrease in spending for the mining company, since this economic decrease in spending will be the result by not having fans turned on where there is no presence of personnel in the area.

Regarding the duration and continuity of the equipment, by activating or deactivating the fan, it will contribute to the useful life of the fans.

\section{REFERENCES}

[1] E. G. HUAHUASONCO TAZA, ““”ANÁLISIS DE INDICADORES ASOCIADOS DE LA OCURRENCIA DE ACCIDENTES LABORALES MORTALES EN TRABAJADORES MINEROS PERUANOS," UNIVERSIDAD NACIONAL DE SAN AGUSTÍN DE AREQUIPA, Arequipa, 2019.

[2] National Geographic Channel, "CHILEAN MINERS:BURIED ALIVE," 2018. https://www.nationalgeographic.com/ (accessed Jun. 29, 2021).

[3] Osinergmin, "Compendio ilustrativo de Accidentes en el Sector de Mediana y Gran Mineria," Lima, 2020. Accessed: Apr. 05, 2021. [Online].

https://www.osinergmin.gob.pe/empresas/mineria/publicaciones.

[4] R. Diaz Flores, "OPTIMIZACIÓN DEL SISTEMA DE VENTILACIÓN COMO UN MÉTODO DE CONTROL DE LA CALIDAD DEL AIRE EN LA MINA SAN RAFAEL, DE LA REGIÓN PUNO"," UNIVERSIDAD NACIONAL DE SAN AGUSTÍN DE AREQUIPA, Arequipa, 2019.

[5] E. Peruano, "NORMAS LEGALES," 2010, Accessed: Apr. 05, 2021. [Online]. Available: https://diariooficial.elperuano.pe/normas. 


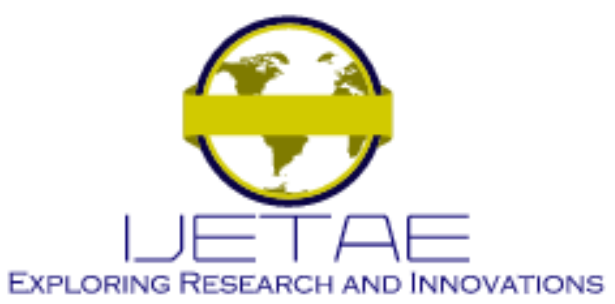

International Journal of Emerging Technology and Advanced Engineering

Website: www.ijetae.com (E-ISSN 2250-2459, Scopus Indexed, ISO 9001:2008 Certified Journal, Volume 11, Issue 09, September 2021)

[6] S. A. Kozyrev and A. V. Osintseva, "Optimizing arrangement of air distribution controllers in mine ventilation system," J. Min. Sci., vol. 48, no. 5, pp. 896-903, Mar. 2012, doi $10.1134 / \mathrm{S} 1062739148050140$.

[7] Espressif, "ESP32-C3-MINI-1 Datasheet ," 2021. https://www.espressif.com/en/support/download/documents. (accessed Jun. 01, 2021).

[8] J. Llanca, J. Hurtado, E. Acuña, and A. Diaz, "Implementación de un Sistema de Ventilación Bajo Demanda en División Andina," Escuelas de minas -Universidad del desarrollo, Santiago de Chile, 2018.

[9] S. K. Sameer, M. Vishnu Teja, and N. S. Chandrahas, "OPTIMIZATION OF ENERGY EFFICIENCY AND ENERGY SAVING POTENTIAL ENERGY USE FOR MINE VENTILATION FAN WITH ADAPTABLE SPEED DRIVE," Int. J. Recent Dev. Sci. Technol., 2018.

[10] M. Semin, L. Levin, L. Y. Levin, and M. A. Semin, "Conception of automated mine ventilation control system and its implementation on Belarussian potash mines Performance evaluation of various methods for dead end ventilation when drum head type miner is used View project Development of the algorithm for automated mine ventilation control on 3-RU and 4-RU potash mines, Belaruskali company View project Conception of automated mine ventilation control system and its implementation on Belarussian potash mines," 2017, Accessed: Apr. 12, 2021. [Online]. Available: https://www.researchgate.net/publication/324182285.

[11] D. F. AMORES PEREZ, "DESARROLLO E IMPLEMENTACION DE UN SISTEMA DE MONITORIZACION, CONTROL Y AUTOMATIZADO PARA UN INVERNADERO TIPO TUNEL," Universidad Andres Bello, Santiago de Chile, 2019.

[12] J. L. Rodriguez Sotelo, A. López Londoño, C. Vega Botero, and R. Flores Hurtado, "SISTEMA DE MONITOREO Y CONTROL REMOTO USANDO IOT PARA UN REGULADOR DE PRESIÓN," Sci. Tech., vol. 221, pp. 391-397, Dec. 2017, Accessed: Sep. 2021. [Online]. Available: https://revistas.utp.edu.co/index.php/revistaciencia/article/view/1329 $1 / 11391$.
[13] L. Aosong Electronics Co, "DTH22 Datasheet," 2017. https://pdf1.alldatasheet.com/datasheetpdf/view/1132459/ETC2/DHT22.html (accessed Jun. 01, 2021).

[14] T.K. Hareendran, “Anemometer," Nov. 24, 2020 https://www.electroschematics.com/anemometer/ (accessed Jun. 29, 2021).

[15] Mouser Electronics, "ADDA USA DC FAN SPECIFICATIONS." https://www.mouser.pe/datasheet/2/6/dclist-3649.pdf (accessed Sep. 06, 2021).

[16] H. International Inc, "Linear Hall-effect sensor ICs ," Feb. 2015. Accessed: Sep. 06, 2021. [Online]. Available: https://sensing.honeywell.com/honeywell-sensing-ss39et-ss49ess59et-product-sheet-005850-3-en.pdf.

[17] Datasheetspdf, "HC-SR501 DETECTOR Datasheet ."

[18] Punto Flotante S.A., "Sensor Infrarojo HC-SR501," 2018. Accessed: Jun. $\quad 2021 . \quad$ [Online]. Available: https://puntoflotante.net/MANUAL-DEL-USUARIO-SENSOR-DEMOVIMIENTO-PIR-HC-SR501.pdf.

[19] ESPRESSIF, "ESP32-S2-DevKitM-Guide latest documentation." https://docs.espressif.com/projects/esp-idf/en/latest/esp32s2/hwreference/esp32s2/user-guide-devkitm-1-v1.html (accessed Sep. 06, 2021).

[20] The Mathworks Inc, "ThingSpeak Internet of Things," 2018. https://thingspeak.com/ (accessed Jun. 15, 2021).

[21] Codmind, “Comprendiendo el protocolo HTTP ," Oct. 08, 2020. https:/www.youtube.com/watch?v=DT8ddet83OM (accessed Jun. 15, 2021)

[22] V. Henriques and R. Malekian, "Mine Safety System Using Wireless Sensor Network," IEEE Access, vol. 4, pp. 3511-3521, 2016, doi: 10.1109/ACCESS.2016.2581844. 